Upon his retirement Donald moved to Austin, Texas. During this period of his life he was active in the St. John's United Methodist Church and worked for many years in the local Meals-onWheels program. He was also a member of the Gray Panthers. Donald loved flowers, especially daylilies, and was active in the Austin Hemerocallis Society.

Donald's first wife, Emily, predeceased him. He is survived by his widow, Anne Strong, and three children, Stuart and Kathleen, both of Austin, and Elizabeth Gitlitz of Bloomington, Indiana. $\mathrm{He}$ is also survived by three grandchildren. He will be greatly missed.

William H. Stewart

The University of Alabama

\section{Marie-France Toinet}

Marie-France Toinet, one of France's premiere interpreters of American political life, passed away on July 31, 1995 at the age of fifty-three. Passion, commitment and integrity defined her scholarship as well as her relations with countless friends and colleagues. As a young Parisian high school student, she came to Delaware on an AFS exchange for one year. This first in-depth experience in America as it entered the 1960 's was to shape her entire intellectual life and serve as the foundation upon which she built her scholarly interest. Many other extensive stays in the United States followed. She was a Harkness Fellow from 1968 to 1970 studying at the University of California, Berkeley and the JFK School of Government, Harvard University. During 1968-69, she also was an APSA Congressional Fellow. In subsequent years, she would be awarded a number of other prestigious fellowships including ICPR Fellow, University of Michigan (1972), Salzburg Seminar in American Studies Fellow (1974), Fulbright Fellow (1978), German Marshall Fund Fellow (1980) and Eisenhower Fellow (1987). Toinet did her studies at the Institut d'Etudes Politiques de Paris and received her doctorate in 1969 from the University of Paris. While her basic position in France was as Director of Research at the Centre d'Etudes et de Recherches Internationales of the Fondation Nationale des Sciences Politiques, she also taught at the university and at Sciences Po in Paris. Given her extraordinary grasp of French as well as American politics, joined with great pedagogical skills, Marie-France Toinet came to the United States frequently as a Visiting Professor: University of California, Irvine (1974 and 1992), University of Iowa (1978), University of Michigan, Ann Arbor (1984), Yale

University (1984), and New York University (1988).

Her premature death deprives us of an extremely creative and productive scholar, who was among the most prominent foreign political scientists interpreting the United States and its governmental institutions. As is more common in Europe, she wrote for the mass media including Le Monde and Le Monde Diplomatique, as well as dozens of articles in such leading French professional journals as the Revue française de science politique, Pouvoirs, Revue d'histoire moderne et contemporaine, and the Revue française d'études américaines. She published a number of books including not only the most important French analyses of Congress (Le Congrès des Etats Unis, PUF 1972), the supreme court (La Cour Suprême des Etats-Unis: les grands arrêts, Nancy, Presses universitaires de Nancy, 1989), and McCarthyism (La chasse aux sorcières, Editions Complexe, 1984), but also the basic French textbook on the American political system [Le systeme politique des Etats-Unis, Paris: PUF, 1987, and 1990 (Second Edition)]. Her most recently completed major work was a co-authored (with Françoise Subileau) comparative study of non-voting in France and the United States (Les chemins de l'abstention: une comparaison francoaméricaine, Paris: Le Découverte, 1993).

The passion which underlay MarieFrance Toinet's scholarship was a dual commitment to democratic equality and to the role of the state as guardian of each and every citizen's basic welfare. In America, she saw the hope (alas unachieved) of equality. She resonated with our openness and search for betterment, while she condemned our nonvoting (because the system denied mobilizing choices to a large proportion of the potential electorate) as well as our categorical thinking as revealed in political correctness. In France, she was always the most faithful of socialists; in contrast to most of her "comrades", she avoided both any search for influence or political office and cynicism with the Mitterrand presidency as it evolved from 1981 to 1995 . In both countries, she systematically spoke and wrote what she believed, never modifying or shaping her views in order to curry favor or placate a potential benefactor. This characteristic was one which her friends cherished even more than her adversaries respected.
Marie-France Toinet was energized by people as well as ideas. She was a gregarious, dynamic, thoughtful, and warm person. Friendship was important to her: she made friends easily and she was a good friend always there to help you through personal or intellectual trials and tribulations. For a whole generation of Americanists and students of French politics, she was a treasured friend. She went out of her way to facilitate the work of American political scientists working in France or just passing through, assisting them in every possible way: feeding them, housing them, introducing them, and providing them with attention as well as intellectual sustenance. Her unparalleled generosity and warmth will by sorely missed by the scores of us who were fortunate enough to be able to say: Marie-France was my friend. Without her, for us Paris will never again be quite what it was. The City of Lights shines less brightly.

William R. Schonfeld

University of California, Irvine

\section{Franz von Sauer}

Franz von Sauer, Oklahoma State University political science professor, passed away on August 16, 1995. He remained, despite a prolonged illness, amiable and jovial to the very end.

As a fresh Georgetown Ph.D., Franz von Sauer was invited to OSU for a job interview in June, 1969. He was an instant hit. He sparkled with the intelligence, charm, and savoire-faire that distinguished him all his life.

Born February 27, 1942, in Vienna, Austria, the second son of world famous pianists Emil von Sauer and Angelica Morales, he fell heir to a rich classical tradition and took an abiding interest in politics and world affairs.

Von Sauer quickly became one of OSU's more colorful faculty members. He published a path-breaking book on Mexico's major opposition party which only recently became the political factor he presciently foresaw it becoming. He carried his school's flag abroad as visiting professor at the University of the Americas, Mexico City, the Universidad Simon Bolivar, Caracas, and the Universidad Central de Venezuela, Caracas. He served with such distinction as a Fulbright lecturer in Venezuela in 1989 that he was asked to extend his stay an additional year. He wrote at the time, "Many of my colleagues here at the UCV think I'm nuts to want to stay in a country where so many of its own citizens are dying to get out, but se- 
cretly they are tickled to death to see that all the adversity we have been through together has not scared me out of Venezuela."

When he did his research, he went out in the field and talked directly to active politicians. His kind of research required tact, understanding, and an ability to assure people it was safe to hold you in their confidence-qualities which he had in abundance.

In his OSU teaching career spanning four decades, he provided students and colleagues a matchless combination of sharp wit, shrewd insight, multiple languages, and uncommon sophistication. $\mathrm{He}$ was a rather exotic flower to bloom on the Oklahoma prairie.

He was wonderfully accessible, office door wide open, easily available to students. He could not walk down the corridor, with its line of offices, without greeting each and every person, laughing and singing.

His courses about Latin America and international affairs were in constant demand. He was not only a knowledgable teacher, but a colorful, stimulating one able to give first-hand accounts of events he experienced abroad. Admiring students and colleagues bestowed on him several well-deserved awards as an outstanding teacher.

Von Sauer had great talent as an amateur musician, writer, raconteur, and quipster, and he put his talents to use in his profession as a teacher. He wrote wonderful hypothetical cases for his students in international law-cases that posed serious disputes to which students could apply all their newlygained legal expertise and which also spoofed prominent officials and institutions. He was resourceful and inventive. His American students were sometimes slow to catch on to the phenomena he was trying to tell them of, but when they did catch on, they caught on with enthusiasm. He instructed them in the golpe de estado. Many in his department remember when his students with fiendish delight wrote a filmscript about a coup d'etat and cast a couple of professors to play key roles in their film about an attempted overthrow of a dictatorial government. This film used to be played at department honors banquests to roars of laughter, and von Sauer rejoiced.

Von Sauer was a great traveler and sender of greetings from remote places. One knew that no matter where he was, he wasn't forgetting his friends, and he wished them well. And that is how he taught all his friends to think of him.

Bertil L. Hanson

Oklahoma State University 